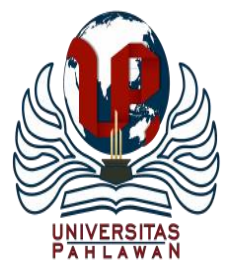

Edukatif : Jurnal Ilmu Pendidikan Volume 3 Nomor 5 Tahun 2021 Halm 2523 - 2530

EDUKATIF: JURNAL ILMU PENDIDIKAN

Research \& Learning in Education

https://edukatif.org/index.php/edukatif/index

\title{
Pembuatan dan Validasi Instrumen Kemampuan Berpikir Kreatif dan Kolaborasi untuk Mengidentifikasi Keterampilan Abad 21 Calon Guru
}

\author{
Oktariani $^{1 凶}$, Asyti Febliza ${ }^{2}$, Nurul Fauziah ${ }^{3}$ \\ Universitas Islam Riau, Indonesia ${ }^{1,2,3}$ \\ E-mail : oktariani@edu.uir.ac.id ${ }^{1}$
}

\begin{abstract}
Abstrak
Penelitian ini dilakukan untuk membuat dan memvalidasi instrumen yang akan digunakan untuk mengidentifikasi keterampilan abad 21 calon guru khususnya keterampilan berpikir kreatif dan keterampilan berkolaborasi. Pengembangan instrumen ini perlu dilakukan mengingat keterampilan abad 21 ini merupakan keterampilan yang harus dimiliki calon guru untuk menghadapi tantangan abad 21. Penelitian ini merupakan penelitian Research and Development (R\&D) dengan menggunakan model pengembangan 4D yang terdiri dari 4 tahapan. Akan tetapi penelitian ini hanya dilakukan sampai 3 tahapan yaitu define, design dan develop. Hasil pengolahan data menunjukkan bahwa instrumen yang dikembangkan valid dengan nilai CVI sebesar 0,86 untuk instrumen keterampilan berpikir kreatif, dan 0,84 untuk keterampilan berkolaborasi. Reliabilitas instrumen termasuk kategori tinggi dengan nilai reliabilitas sebesar 0,78 untuk instrumen keterampilan berpikir kreatif dan 0,756 untuk instrumen keterampilan berkolaborasi. Jadi, instrumen yang dikembangkan dalam penelitian ini dapat digunakan untuk mengidentifikasi keterampilan berpikir kreatif dan kolaborasi calon guru.

Kata Kunci: berpikir kreatif, keterampilan abad 21,kolaborasi,reliabilitas, validitas.
\end{abstract}

\section{Abstract}

This research was conducted to create and validate the instruments that will be used to indentify $21^{\text {st }}$ Century skills of pre-service teacher especially creative thinking and collaborative skills. The development of this instrument is important to held because these $21^{\text {st }}$ Century skills are skills that pre-service teacher must posses to face the challenges of the $21^{\text {st }}$ Century. This research was Research and Development $(R \& D)$ by using $4 D$ development model consisting of 4 stage. However, this research only reached 3 step, define, design dan develop. The result of analysis data showed that the instrument was valid based on CVI value were 0,86 for creative thinking skills instrument and 0,84 for collaborative skills instrument. Reliability of instruments were clasified as in high category with reliability value were 0,78 for creative thinking skills instrument and 0,756 for collaborative skills instrument. So, the instrument that develop in this study can be used to identify creative thinking and collaborative skills of pre-service teacher.

Keywords: creative thinking, $21^{\text {st }}$ Century skills, collaborative, reliability, validity.

Copyright (c) 2021 Oktariani, Asyti Febliza, Nurul Fauziah

$\triangle$ Corresponding author

Email : oktariani@edu.uir.ac.id

DOI : https://doi.org/10.31004/edukatif.v3i5.841

ISSN 2656-8063 (Media Cetak)

ISSN 2656-8071 (Media Online) 
2524 Pembuatan dan Validasi Instrumen Kemampuan Berpikir Kreatif dan Kolaborasi untuk Mengidentifikasi Keterampilan Abad 21 Calon Guru - Oktariani, Asyti Febliza, Nurul Fauziah

DOI: https://doi.org/10.31004/edukatif.v3i5.841

\section{PENDAHULUAN}

Era industri 4.0 yang sekarang kita hadapi adalah era dimana kita mengenal adanya proses digitalisasi yang dipengaruhi oleh beberapa faktor yaitu: peningkatan konektivitas dan komputerisasi; adanya analisis terhadap kecerdasan dan kemampuan bisnis; adanya kecerdasan buatan dalam bentuk robotik, 4D printing dan digitalisasi (Lee, et.al., 2013; Maria, M.; Shahbodin, F.; dan Pee, 2016; (P21)., 2018). Hal ini tentu menuntut kesiapan segala aspek termasuk sumber daya manusia. Tidak hanya dari sisi pengetahuannya saja tetapi juga keterampilan dan kemampuan untuk menghadapi era 4.0 ini.

Salah satu faktor penting dalam menghasilkan sumber daya manusia yang siap menghadapi era 4.0 adalah pendidikan. Pendidikan harus bisa mengikuti perkembangan dan perubahan zaman agar tetap berjalan efektif. Perubahan zaman seiring dengan masuknya era 4.0 menuntut tranformasi pendidikan agar proses pendidikan berjalan sesuai dengan kondisi dan keperluan peserta didik di era 4.0 ini. Oleh sebab itu dikenal istilah pendidikan 4.0. Pendidikan 4.0 merupakan bentuk usaha sadar dan terencana oleh praktisi pedidikan yang bertujuan agar bisa memfasilitasi peserta didik dalam mengasah dan mengembangkan kompetensi berpikir, berbuat dan bisa bertahan hidup dan bersaing di era 4.0 yang dikenal juga dengan istilah kompetensi 4.0 atau keterampilan abad 21 (Greenstein, 2012).

US-based Partnership for 21st Century skills ((P21)., 2018) mengemukakan bahwa kemampuan yang diperlukan oleh SDM untuk menghadapi era 4.0 ini adalah "The 4Cs" yaitu komunikasi (Communication), kolaborasi (Collaboration), berpikir kritis dan kreatif (Critical Thinking and Creativity). Di sisi lain para ahli juga mengemukakan bahwa untuk bertahan dan bisa bersaing di era 4.0 ada beberapa kompetensi yang diperlukan diantaranya: keterampilan berpikir kritis (critical thinking skills), keterampilan pemecahan masalah (problem solving skills), kolaborasi dan kepemimpinan (collaboration and leadership), kemampuan beradaptasi, enterpreneurship, keterampilan berkomunikasi, keterampilan mengakses dan menganalisis informasi serta rasa ingin tahu dan imajinasi yang tinggi (Redhana, 2019; Wagner, 2017; Firman, 2018).

Beberapa penelitian sebelumnya menunjukkan hasil bahwa perlu adanya peningkatan kompetensi SDM untuk menghadapi era 4.0 ini melalui pendidikan dan pembelajaran. Masih kurangnya kompetensi keterampilan berpikir kritis, pemecahan masalah, berkomunikasi, berkolaborasi dan pemanfaatan IPTEK lulusan SMA/SMK, diploma maupun perguruan tinggi (Meutiah et al., 2019; Nur, Wan, Harun, \& Shukor, 2019; Oktariani, Febliza, \& Fauziah, 2020; Sari \& Hidayat, 2017; Tohir, 2019; Trilling, B dan Fadel, 2009). Untuk itu perlu adanya usaha dari dunia pendidikan untuk bisa meningkatkan keterampilan abad 21 peserta didik melalui pembelajaran.

Pengembangan keterampilan abad 21 pada pembelajaran perlu perencanaan yang sistematis dan terarah. Pembelajaran yang berpusat pada siswa dan menggunakan pendekatan saintifik seperti model pembelajaran berbasis projek, pemecahan masalah, dan penemuan saat ini menjadi salah satu upaya untuk mengembangkan keterampilan abad 21. Tidak hanya sebagai bekal untuk menghadapi abad 21, keterampilan abad 21 ini juga terbukti dapat meningkatkan prestasi dan capaian akademik siswa dalam proses pembelajaran (Chairani, 2019; Greenstein, 2012; Nuraeni, Feronika, \& Yunita, 2019).

Sesuai penjelasan di atas jelas bahwa keterampilan berpikir kreatif dan kolaborasi merupakan keterampilan abad 21 yang harus dimiliki oleh peserta didik. Keterampilan berpikir kreatif merupakan keterampilan untuk menemukan hal baru yang orisinil serta mampu merumuskan berbagai ide untuk menyelesaikan setiap masalah, dan menggunakan kemampuan tersebut untuk menghasilkan pemikiran baru yang unik dan bervariasi (Afandi, Sajidan, Akhyar, \& Suryani, 2019; Kadayifcia, H.; Atasoy, B.; \& Akkus, 2012). Kemampuan ini merupakan kemampuan yang menjadi penentu kualitas suatu bangsa dan sangat dibutuhkan oleh peserta didik nantinya di dunia kerja. Keterampilan berpikir kreatif dapat dilihat dari beberapa indikator keterampilan berpikir kreatif yang terdiri dari: Kelancaran, Keluwesan, Orisinalitas, Elaborasi dan Evaluasi. 
Keterampilan berkolaborasi merupakan keterampilan yang dimiliki seseorang untuk dapat bekerjasama secara efektif dan saling toleransi dengan anggota tim, serta melatih kelancaran dalam pengambilan keputusan untuk mencapai tujuan bersama (Trilling, B dan Fadel, 2009). Keterampilan ini juga merupakan salah satu keterampilan ang dibutuhkan di dunia kerja. Seseorang yang memiliki keterampilan berkolaborasi akan dapat bekerja sama dengan rekan kerjanya yang berbeda karakter dan latarbelakang untuk menghasilkan sebuah karya yang berkualitas demi mencapai tujuan bersama. Keterampilan berpikir kolaborasi juga menjadi salah satu solusi bagi peserta didik untuk mengahadapi kesulitan belajar (Ayun, 2021; Hayat, Rustaman, Rahmat, \& Redjeki, 2019).

Pengembangan keterampilan abad 21 dalam pembelajaran perlu juga diiringi dengan pengembangan alat ukur yang dapat membantu mengidentifikasi dan memetakan keterampilan abad 21 yang dimiliki oleh peserta didik. Informasi dan data terkait profil keterampilan abad 21 ini sangat diperlukan oleh para pengambil kebijakan seperti pemerintah, guru dan dosen agar mereka dapat menentukan strategi dan langkah praktis untuk dapat mengembangkan dan meningkatkan keterampilan abad 21 peserta didik. Sementara sejauh ini penelitian terkait pengembangan instrumen pengukuran keterampilan abad 21 masih sangat terbatas. Pembuatan alat evaluasi dan assesmen ini juga yang digunakan untuk meningkatkan keterampilan berpikir kreatif dan kolaborasi. Sebab, adanya evaluasi akan menuntut mahasiswa untuk menunjukkan kinerja yang maksimal sebagai bentuk pencapaian prestasi belajarnya. Sehingga, jika tes yang diberikan menuntut siswa untuk mengembangkan keterampilan tertentu, maka mahasiswa akan berusaha untuk melatih keterampilan tersebut untuk mendapatkan hasil maksimal (Oktariani et al., 2020). Evaluasi atau assesmen keterampilan abad 21 terdiri dari berbagai bentuk yang disesuaiakan dengan kebutuhan diantaranya, soal tes yang terintegrasi dengan pembelajaran, peer atau self assesment dalam bentuk angket, kusisoner, daftar cek, dsb., atau bisa dalam bentuk observasi, wawancara maupun tes tulisan (Ayun, 2021; Care, Kim, Vista, \& Anderson, 2018; Chu, Reynolds, Tavares, Notari, \& Lee, 2016; Djupanda, 2015; Erdogan et al., 2019; Hadma Yuliana, Mariati, Resa Yulianti, 2017; Lestari, Nyeneng, \& Herlina, 2019; Moza, Sesanti, \& Marsitin, 2020; Rahmi \& Erlidawati, 2016; Tohir, 2019; Warner \& Kaur, 2017)

Oleh sebab itu, peneliti merasa perlu melakukan penelitian yang bertujuan untuk membuat dan memvalidasi instrumen untuk mengukur keterampilan berpikir kreatif dan kolaborasi. Instrumen ang dibuat dalam penelitian ini nantinya dapat digunakan dengan cara self assesment, peer assesment maupun teacher assesment. Dengan adanya instrumen yang valid dan reliabel yang dihasilkan dari penelitian ini, peneliti dapat melakukan follow up dengan melakukan penelitian lanjutan untuk mengidentifikasi dan memetakan keterampilan berpikir kreatif dan kolaborasi calon guru sehingga selanjutnya dapat ditentukan strategi lanjutan untuk mengembangkan dan meningkatkan keterampilan abad 21 calon guru.

\section{METODE PENELITIAN}

Metode penelitian yang digunakan dalam penelitian ini adalah penelitian Research and Development, yang bertujuan untuk menghasilkan produk tertentu, dan menguji keefektifan produk tersebut. Instrumen dalam penelitian ini dibuat melalui tahapan model pengembangan 4D yang terdiri dari 4 tahapan yaitu: define, design, develop and dissemination. Dalam penelitian ini peneliti hanya sampai pada tahap develop. Pada tahap define, peneliti melakukan studi awal sesuai dengan kebutuhan penelitian. Pada tahap design, peneliti merancang dan merumuskan perangkat instrumen mulai dari kisi-kisi, bentuk instrumen, pedoman atau rubrik penilaian untuk selanjutnya divalidasi. Pada tahap develop, instrumen yang sudah dirancang selanjutnya divalidasi oleh ahli untuk menentukan validitas isi dan konstruk instrumen. Hasil validasi ini kemudian direvisi dan selanjutnya diujicobakan dalam skala terbatas untuk menentukan reliabilitas tes.

Pada tahap studi awal, peneliti melakukan studi pustaka dan lapangan untuk mengumpulkan data dan informasi terkait teori-teori, bentuk pengukuran dan indikator, pelaksanaan dan gambaran di lapangan, serta 
penelitian terkait keterampilan berpikir kreatif dan kolaborasi. Data dan informasi ini dikumpulkan melalui analisis dokumen, observasi dan waawancara. Data dan informasi ini dijadikan sebagai acuan peneliti untuk melanjutkan tahapan penelitian berikutnya.

Pada tahap perancangan, peneliti mulai merumuskan indikator pengukuran, kisi-kisi, rubrik dan bentuk instrumen. Dalam merancang instrumen, peneliti juga mengacu pada beberapa tes yang sudah terstandar yang dikembangkan oleh International Reading Association (IRA) (Read Write Think 2005) dan Torrance Test of Creatie Thinking. Pada tahap ini, peneliti kemudian mengembangkan draft instrumen dalam bentuk kuisioner yang nantinya dapat diisi langsung oleh siswa atau mahasiswa, teman sejawat maupun pengajar (guru dan dosen). Draft ini kemudian dikembangkan dan disiapkan untuk nantinya melalui tahapan pengembangan.

Selanjutnya, tahap pengembangan, dilakukan tahap validasi dibantu oleh 3 orang validator ahli dan 5 orang mahasiswa untuk uji keterbacaan. Temuan-temuan dalam tahapan ini dijadikan dasar untuk menyempurnakan draft instrumen yang sudah dibuat. Kemudian, dilakukan uji coba terbatas dilakukan dengan melibatkan 20 orang mahasiswa. Selanjutnya dilakukan pengolahan data untuk mendapatkan nilai validitas dan reliabilitas instrumen sebagai dasar penentuan kelayakan instrumen.

\section{HASIL DAN PEMBAHASAN PENELITIAN}

Penelitian ini menghasilkan instrumen yang valid reliabel untuk mengidentifiksi dan memetakan keterampilan berpikir kreatif dan keterampilan berkolaborasi calon guru. Berdasarkan pengumpulan dan analisis data, untuk membuat instrumen peneliti melakukan studi awal dengan menganalisis dokumen, observasi dan wawancara. Berdasarkan studi awal ini didapatkanlah beberapa teori dasar dan contoh instrumen yang berkaitan dengan keterampilan berpikir kreatif dan keterampilan berkolaborasi, diantaranya instrumen yang dikembangkan oleh International Reading Association (IRA) (Read Write Think 2005) dan Torrance Test of Creative Thinking. Mengacu pada hasil studi awal ini peneliti kemudian merencanakan bentuk instrumen, kisi-kisi dan rubrik penilaian. Berdasarkan hal tersebut dibuatlah rancangan instrumen dalam bentuk kuisioner baik untuk mengukur keterampilan berpikir kreatif maupun keterampilan berkolaborasi.

Untuk kuisioner keterampilan berpikir kreatif dikembangkan berdasarkan indikator berpikir keterampilan kreatif. Indikator berpikir kreatif yang menjadi dasar penyusunan instrumen ini adalah kelancaran, keluwesan, orisinalitas, elaborasi, dan evaluasi. Sedangkan untuk kuisioner keterampilan berkolaborasi dikembangkan berdasarkan indikator keterampilan berkolaborasi. Indikator tersebut adalah: kontribusi, manajemen waktu, pemecahan masalah, kerjasama, penyelidikan dan sintesis.

Hasil perancangan ini didapatkanlah draft instrumen kuisioner keterampilan berpikir kreatif yang terdiri atas 20 item dan kuisioner keterampilan berkolaborasi yang terdiri dari 20 item pertanyaan. Masing-masing item pertanyaan ini terdiri atas 4 pilihan jawaban yaitu: tidak pernah, pernah, sering dan selalu. Pilihan jawaban ini nantinya akan dikuantisasi sesuai respon dari responden untuk selanjutnya dikategorikan sesuai tingakatan keterampilan responden. Kuisioner ini dapat diadaptasi kembali sesuai dengan cara pengisiannya. Jika kusioner ini akan diisi langsung oleh yang akan dinilai maka instrumen dapat dikembangkan menjadi kuisioner yang bersifat self assesment. Jika kusioner ini akan diisi oleh teman sejawat yang akan dinilai maka instrumen dapat dikembangkan menjadi kuisioner yang bersifat peer-assesment. Kuisioner ini juga dapat diisi oleh guru, pengajar maupun observer.

Draft ini kemudian divalidasi oleh 3 orang ahli yang merupakan dosen senior dengan pengalaman mengajar yang lebih dari 10 tahun. Ahli ini membantu peneliti dengan memberikan saran, kritik, perbaikan dan respon yang bermanfaat bagi penyempurnaan kedua instrumen ini. Berdasarkan hasil pengolahan data hasil validasi dan uji coba didapatkan: 
2527 Pembuatan dan Validasi Instrumen Kemampuan Berpikir Kreatif dan Kolaborasi untuk Mengidentifikasi Keterampilan Abad 21 Calon Guru - Oktariani, Asyti Febliza, Nurul Fauziah

DOI: https://doi.org/10.31004/edukatif.v3i5.841

\section{Validitas dan Reliabilitas Keterampilan Berpikir Kreatif}

Dari hasil perhitungan nilai CVR (Content Validity Ratio) dan CVI (Content Validity Index) instrumen keterampilan berpikir kreatif calon guru berdasarkan pertimbangan (judgement) para ahli, dari 20 item pertanyaan didapat 18 item pertanyaan yang valid. Artinya 18 item ini dapat digunakan untuk mengukur dan memetakan keterampilan berpikir kreatif. Dari 18 item ini peneliti hanya memilih 15 item pertanyaan dengan nilai CVR yang tinggi. Secara keseluruhan nilai CVI dari kuisioner keterampilan berpikir kreatif ini adalah sebesar 0,86. Ini artinya instrumen ini memiliki tingkat validitas pada kategori sangat tinggi. Artinya, kuisioner yang dikembangkan dalam penelitian ini dapat mengukur keterampilan berpikir kreatif calon guru. Sesuai dengan pernyataan ahli dan penelitian sebelumnya yang menyatakan bahwa, sebuah instrumen yang valid akan dapat mengkur apa yang hendak di ukur (Hidayati, Sabtiawan, \& Subekti, 2017; Oktariani oktariani; Asyti Febliza; Yelfira Sari, 2019; Saputri, Adlim, \& Inda Rahmayani, 2018). Meskipun, masih terdapat beberapa catatan dari tenaga ahli sebagai bahan pertimbangan untuk perbaikan instrument.

Selain valid, sebuah instrumen juga dituntut untuk memiliki reliabilitas. Sebuah instrumen dikatakan reliabel jika instrumen digunakan pada objek yang sama secara berkali-kali akan menunjukkan hasil yang konsisten (arikunto, 2012; Harry, 2013). Perhitungan reliabilitas kuisioner ini menggunakan software IBMSPSS 20. Setelah dilakukan perhitungan reliabilitas kuisioner keterampilan berpikir kreatif ini maka diperoleh nilai $\alpha=0,78$. Sesuai dengan kriteria reliabilitas, maka kuisioner keterampilan berpikir kreatif ini memiliki nilai reliabilitas yang tergolong dalam kategori tinggi. Suatu instrumen yang memiliki taraf reliabilitas yang tinggi maka tes tersebut dapat memberikan hasil yang tetap setiap kali digunakan (Hidayati et al., 2017; Redhana, 2015).

\section{Validitas dan Reliabilitas Keterampilan Berkolaborasi}

Dari hasil perhitungan nilai CVR (Content Validity Ratio) dan CVI (Content Validity Index) instrumen keterampilan berkolaborasi calon guru berdasarkan pertimbangan (judgement) para ahli, dari 20 item pertanyaan didapat 14 item pertanyaan yang valid. Artinya 14 item ini dapat digunakan untuk mengukur dan memetakan keterampilan berkolaborasi. Dari 14 item ini peneliti membuat 15 item pertanyaan dari 14 item dengan nilai CVR yang tinggi dan 1 item yang sebelumnya tidak valid lalu diperbaiki dan divalidasi kembali sehingga item ini menjadi layak digunakan. Secara keseluruhan nilai CVI dari kuisioner keterampilan berkolaborasi ini adalah sebesar 0,84 . Ini artinya instrumen ini memiliki tingkat validitas pada kategori sangat tinggi. Artinya, kuisioner yang dikembangkan dalam penelitian ini dapat mengukur keterampilan berkolaborasi calon guru. Sesuai dengan pernyataan ahli dan penelitian sebelumnya yang menyatakan bahwa, sebuah instrumen yang valid akan dapat mengkur apa yang hendak di ukur (Hidayati et al., 2017; Oktariani oktariani; Asyti Febliza; Yelfira Sari, 2019; Saputri et al., 2018).

Selain valid, sebuah instrumen juga dituntut untuk memiliki reliabilitas. Sebuah instrumen dikatakan reliabel jika instrumen digunakan pada objek yang sama secara berkali-kali akan menunjukkan hasil yang konsisten (arikunto, 2012; Harry, 2013). Perhitungan reliabilitas kuisioner ini menggunakan software IBMSPSS 20. Setelah dilakukan perhitungan reliabilitas kuisioner keterampilan berkolaborasi ini maka diperoleh nilai $\alpha=0,756$. Sesuai dengan kriteria reliabilitas, maka kuisioner keterampilan berkolaborasi ini memiliki nilai reliabilitas yang tergolong dalam kategori tinggi. Suatu instrumen yang memiliki taraf reliabilitas yang tinggi maka tes tersebut dapat memberikan hasil yang tetap setiap kali digunakan (Hidayati et al., 2017; Redhana, 2015).

Berdasarkan data ini maka dapat dikatakan bahwa kedua instrumen keterampilan berpikir kreatif dan keterampilan berkolaborasi calon guru ini valid dan reliabel. Kuisioner ini digunakan sebagai salah satu cara untuk mengetahui dan memetakan keterampilan berpikir kreatif dan keterampilan berkolaborasi calon guru. Instrumen ini nantinya dapat diadaptasi oleh bidang ilmu lainnya agar dapat digunakan sebagai alat pengukur dan pengidentifikasi kemampuan berpikir kreatif dan kolaborasi. Instrumen ini juga dapat digunakan dengan 
2528 Pembuatan dan Validasi Instrumen Kemampuan Berpikir Kreatif dan Kolaborasi untuk Mengidentifikasi Keterampilan Abad 21 Calon Guru - Oktariani, Asyti Febliza, Nurul Fauziah

DOI: https://doi.org/10.31004/edukatif.v3i5.841

metode self assesment, peer assesment maupun teacher assesment. Dari instrumen ini juga peneliti dapat melanjutkan penelitian selanjutnya untuk bisa memetakan keterampilan berpikir kreatif dan keterampilan berkolaborasi calon guru yang berguna bagi dosen, maupun penyusun kurikulum dalam rangka meningkatkan keterampilan abad 21 khususnya keterampilan berpikir kreatif dan keterampilan berkolaborasi calon guru.

\section{KESIMPULAN}

Berdasarkan analisa data penelitian, dapat disimpulkan bahwa instrumen keterampilan berpikir kreatif dan keterampilan berkolaborasi calon guru yang dikembangkan valid dan reliabel. Artinya instrumen ini sudah layak untuk digunakan sebagai salah satu cara untuk mengetahui sejauh mana keterampilan berpikir kreatif dan keterampilan berkolaborasi calon guru. Dari instrumen ini juga peneliti dapat melanjutkan penelitian selanjutnya untuk bisa memetakan keterampilan berpikir kreatif dan keterampilan berkolaborasi calon guru ini valid dan reliabel yang berguna bagi para pengambil kebijakan untuk penyusunan kurikulum, metode dan strategi pembelajaran, penyusunan alat evaluasi dsb sebagai upaya untuk meningkatkan keterampilan abad 21 khususnya keterampilan berpikir kreatif dan keterampilan berkolaborasi calon guru agar siap bersaing dan menghadapi tantangan abad 21 .

\section{UCAPAN TERIMA KASIH}

Penelitian ini tidak akan berjalan lancar tentunya tanpa adanya bantuan dari berbagai pihak seperti validator, responden, serta rekan-rekan kerja yang menjadi teman diskusi untuk pelaksanaan penelitian ini. Selain itu, penelitian ini juga terselenggara dengan adanya bantuan pendanaan dari pihak LPPM UIR. Untuk itu tim penulis ingin berterimakasih kepada seluruh pihak yang membantu jalannya penelitian ini.

\section{DAFTAR PUSTAKA}

Afandi, Sajidan, Akhyar, M., \& Suryani, N. (2019). Development Frameworks Of The Indonesian Partnership $21^{\text {st }}$-Century Skills Standards For Prospective Science Teachers: A Delphi Study. Jurnal Pendidikan IPA Indonesia, 8(1), 89-100. Https://Doi.Org/10.15294/Jpii.V8i1.11647

Arikunto, Suharsimi. (2012). Dasar-Dasar Evaluasi Pendidikan. Jakarta: Bumi Aksara.

Ayun, Q. (2021). Analisis Tingkat Literasi Digital Dan Keterampilan Kolaborasi Siswa Dalam Pembelajaran IPA Kelas VII Secara Daring. Jurnal Didaktika Pendidikan Dasar, 5(1), 271-290. Https://Doi.Org/10.26811/Didaktika.V5i1.286

Care, E., Kim, H., Vista, A., \& Anderson, K. (2018). Education System Alignment For 21 st Century Skills: Focus On Assessment. Center For Universal Education At The Brookings Institution., (January), 1-40. Retrieved From Https://Cutt.Us/0eekq

Chairani, R. P. \& M. (2019). Penerapan Model Pembeljaran Berbasis Masalah Untuk Melatihkan Kemampuan Berpikir Kritis Peserta Didik Pada Materi Larutan Penyangga Kelas XI Di MAN 1 Sidoarjo. Unesa Journal Of Chemical Education, 8(1), 16-21.

Chu, S. K. W., Reynolds, R. B., Tavares, N. J., Notari, M., \& Lee, C. W. Y. (2016). 21st Century Skills Development Through Inquiry-Based Learning: From Theory To Practice. 21st Century Skills Development Through Inquiry-Based Learning: From Theory To Practice, (January), 1-204. Https://Doi.Org/10.1007/978-981-10-2481-8

Djupanda, H. (2015). SMA Dalam Memecahkan Masalah Fisika. Jurnal Pendidikan Fisika Tadulako (JPFT), $3(2), 3-8$.

Erdogan, V., Yang, J., Dahl Olli, Bondeson, D., Mathew, A. P., Oksman, K., ... Anwar, S. (2019). 
2529 Pembuatan dan Validasi Instrumen Kemampuan Berpikir Kreatif dan Kolaborasi untuk Mengidentifikasi Keterampilan Abad 21 Calon Guru - Oktariani, Asyti Febliza, Nurul Fauziah DOI: https://doi.org/10.31004/edukatif.v3i5.841

Keterampilan Berpikir Kreatif Siswa Dalam Menyelesaikan Soal Olimpiade Matematika Berdasarkan Level Metakognisi. Alifmatika: Jurnal Pendidikan Dan Pembelajaran Matematika, 1(1), 1-14. Https://Doi.Org/10.1109/MTAS.2004.1371634

Firman, H. (2018). Mewujudkan Pendidikan Kimia Di Era Industri 4.0: Pembelajaran Berbasis STEM Sebagai Alternatif. Keynote. Seminar Nasional Pendidikan Kimia Dalam Tantangan Revolusi Industri 4.0. Jakarta.

Greenstein, L. (2012). Assesing 21st Century Skills: A Guide To Evaluating Mastery And Authentic Learning. Corwin.: Thousand Oaks, CA.

Hadma Yuliana, Mariati, Resa Yulianti, C. H. (2017). Keterampilan Berpikir Kreatif Pada Siswa Sekolah Menengah Di Palangka Raya Menggunakan Pendekatan Saintifik. Jurnal Pendidikan Fisika Dan Keilmuan (JPFK), 3(1), 48-56.

Harry, F. (2013). Evaluasi Pembelajaran Kimia. Bandung: Jurusan Pendidikan Kimia FPMIPA UPI.

Hayat, M. S., Rustaman, N. Y., Rahmat, A., \& Redjeki, S. (2019). Perkembangan Keterampilan Komunikasi Dan Kolaborasi Mahasiswa Dalam Pembelajaran Inkuiri Berorientasi Entrepreneurship Pada Mata Kuliah Keanekaragaman Tumbuhan. Mangifera Edu, 4(1), 19-31. Https://Doi.Org/10.31943/Mangiferaedu.V4i1.41

Hidayati, S. N., Sabtiawan, W. B., \& Subekti, H. (2017). Pengembangan Instrumen Penilaian Otentik: Validitas Teoritis Dan Kepraktisan. Jurnal Penelitian Pendidikan IPA, 1(1), 22. Https://Doi.Org/10.26740/Jppipa.V1n1.P22-26

Kadayifcia, H.; Atasoy, B.; \& Akkus, H. (2012). The Correlation Between The Flaws Students Define In An Argument And Their Creative And Critical Thinking Abilities. Sciences,. Procedia Social And Behavioral, 47, 802 - 806.

Lee, J., Lapira, E., Bagheri, B., Kao, H. (2013). Recent Advances And Trends In Predictive Manufacturing Systems In Big Data Environment. Manuf. Lett., 1(1), 38-41.

Lestari, T., Nyeneng, I. D. P., \& Herlina, K. (2019). Membangun Keterampilan Berpikir Kreatif Siswa Melalui LKPD Berbasis Scientific Approach Materi Elastisitas Dan Hukum Hooke: Penelitian Pendahuluan. (1), 198-208.

Maria, M.; Shahbodin, F.; Dan Pee, N. C. (2016). Malaysian Higher Education System Toward Industry 4.0Current Trends Overview. Proceeding Of The 3rd International Conference On Applied Science And Technology (AIP) Publishing), 1-7.

Moza, M. P. M., Sesanti, N. R., \& Marsitin, R. (2020). Analisis Kemampuan Berpikir Kreatif Peserta Didik Pada Materi Perbandingan. Pi: Mathematics Education Journal, 3(2), 1-7. Https://Doi.Org/10.21067/Pmej.V3i2.4531

Nur, W., Wan, T., Harun, J., \& Shukor, N. A. (2019). Problem Based Learning To Enhance Students Critical Thinking Skill Via Online Tools. 15(1), 14-23. Https://Doi.Org/10.5539/Ass.V15n1p14

Nuraeni, S., Feronika, T., \& Yunita, L. (2019). Implementasi Self-Efficacy Dan Keterampilan Berpikir Kritis Siswa Pada Pembelajaran Kimia Di Abad 21. 1, 49-56.

Oktariani, O., Febliza, A., \& Fauziah, N. (2020). Keterampilan Berpikir Kritis Calon Guru Kimia Sebagai Kesiapan Menghadapi Revolusi Industri 4.0. Journal Of Natural Science And Integration, 3(2), 114. Https://Doi.Org/10.24014/Jnsi.V3i2.8791

Oktariani Oktariani; Asyti Febliza; Yelfira Sari. (2019). Pembuatan Dan Validasi Tes Pengetahuan Kesehatan Dan Keselamatan Kerja Laboratorium Calon Guru Kimia. JEDCHEM (Journal Education And Chemistry, 1(2), 94-99.

P21., P. For 21st C. Skills. (2018). Framework For 21 Century Learning. Retrieved From Http://Www.P21.Org/Our-Work/P21framework. 
2530 Pembuatan dan Validasi Instrumen Kemampuan Berpikir Kreatif dan Kolaborasi untuk Mengidentifikasi Keterampilan Abad 21 Calon Guru - Oktariani, Asyti Febliza, Nurul Fauziah

DOI: https://doi.org/10.31004/edukatif.v3i5.841

Rahmi, D. R., \& Erlidawati. (2016). Identifikasi Kemampuan Berpikir Kreatif Siswa Kelas XI Menggunakan Soal Open-Ended Problem Pada Materi Koloid Di SMA/MA Kota Banda Aceh. Jurnal Ilmiah Mahasiswa Pendidikan Kimia, 1(4), 60-69.

Redhana, I. W. (2015). Pengembangan Tes Keterampilan Berpikir Kreatif. Jurnal Pendidikan Dan Pengajaran, 48(1-3). Https://Doi.Org/10.23887/Jppundiksha.V48i1-3.6915

Redhana, I. W. (2019). Mengembangkan Keterampilan Abad Ke-21 Dalam Pembelajaran Kimia. Jurnal Inovasi Pendidikan Kimia, 13(1).

Saputri, N., Adlim, A., \& Inda Rahmayani, R. F. (2018). Pengembangan Instrumen Penilaian Psikomotorik Untuk Praktikum Kimia Dasar. Jurnal Tadris Kimiya, 3(2), 114-124. Https://Doi.Org/10.15575/Jtk.V3i2.3444

Sari, S., \& Hidayat, R. Y. (2017). Pengembangan Keterampilan Berpikir Kreatif Siswa Pada Praktikum JenisJenis Koloid: Pendekatan Sainstifik. Jurnal Tadris Kimia, $1(1), \quad 32$. Https://Doi.Org/10.15575/Jta.V1i1.1155

Tohir, M. (2019). Keterampilan Berpikir Kreatif Siswa Dalam Menyelesaikan Soal Olimpiade Matematika Berdasarkan Level Metakognisi. Alifmatika: Jurnal Pendidikan Dan Pembelajaran Matematika, 1(1), 114. Https://Doi.Org/10.35316/Alifmatika.2019.V1i1.1-14

Trilling, B Dan Fadel, C. (2009). 21st Century Skills : Learning For Life In Our Times. San Francisco: California Jossey-Bass/ John Willey \& Sons. Inc.

Wagner, T. (2017). Overcoming The Global Achievement Gap. Retrieved January 20, 2019, From Https://Www.Cosa.K12.Or.Us/Downloads/Profdev/Seaside 2009/Tony Wagner.Pdf.

Warner, S., \& Kaur, A. (2017). The Perceptions Of Teachers And Students On A 21 St Century Mathematics Instructional Model. International Electronic Journal Of Mathematics Education E-ISSN:, 12(2), 193215. 